\section{Summary points}

The four new UK medical schools are implementing key reforms in medical education; they show considerable similarities in their approaches to curricular design and learning methods

Key features are integrated curriculums with patient contact throughout the course

Academic training of research methods through student options is central

Altered selection criteria is leading to a different student mix, even in non-graduate entry programmes

These four new medical schools aspire to be the pioneers of 21st century medical education, driven by the enthusiasm of local champions and the need to expand the national workforce. Their shared vision suggests a common set of educational principles, firmly grounded in best current practice but seeking to discover new routes to the goal of quality teaching and learning. The benefits should come to all-when we need the help of one of the next generation of doctors.

Since this article was written, JS has become dean at Griffith Medical School, Griffith University, Australia.

Contributors and sources: All authors contributed equally to identifying key educational issues and providing specific data from their school. AH coordinated the first drafts, with much help from all in further revisions. The sources of data are largely from the experience of the authors as senior faculty at these schools comparing their approaches to other institutions, and referencing this to the literature.

Funding: None.

Competing interests: None declared.

1 Higher Education Funding Council for England. Increasing medical student numbers in England (Report 01/31). Bristol: HEFCE, 2001

2 General Medical Council. Tomorrow's doctors. London: GMC, 2003

Usherwood T, Joesbury H, Hannay D. Student directed problem based learning in general practice and public health. Med Educ 1991;25:421-9.

Hafferty FW. Into the valley: death and the socialization of medical students. London: Yale University Press, 1991.

5 Silverman J, Kurtz S, Draper J. Skills for communicating with patients. Abingdon: Radcliffe Medical Press, 1998.

6 Asch E, Saltzberg D, Kaiser S. Reinforcement of selfdirected learning and the development of professional attitudes through peer and self the development of professional
assessment. Acad Med 1998;73:575.

7 Sinclair S. Making doctors: an institutional apprenticeship. Oxford: Berg,

8 Universities UK. Social class and participation: good practice in widening access to higher education. London: UUK, 2002.

9 Holmes D. Eight years experience of widening access to medical education. Med Educ 2002;36:979-84

10 Australian Council for Educational Research. Graduate Australian medical schools admissions test UK: information booklet 2002-2003. Cheltenham: Universities and Colleges Admissions Service, 2002.

11 Harden RM, Crosby JR, Davis MH, Friedman M. Outcome-based education 5-from competency to meta-competency: a model for the specification of learning outcomes. AMEE Guide 14. Med Teach 1999;21:546-52.

12 Harden RM, Stamper N. What is a spiral curriculum? Med Teach 1999;21:141-3.

13 David T, Patel N, Burdett K, Rangachari P. Problem based learning in medicine. London: Royal Society of Medicine, 1999.

14 Van der Vleuten CPM, Verwijnen GM, Wijnen WHFW. Fifteen years of experience with progress testing in a problem-based learning curriculum. Med Teach 1996;18:103-9.

15 Department for Education and Skills. The future of higher education. London: Stationery Office, 2003. (www.dfes.gov.uk/hegateway/strategy/ hestrategy/pdfs/DfES-HigherEducation.pdf, accessed 5 Jul 2004).

16 Prideaux D, Bligh J. Research in medical education: asking the right questions. Med Educ 2002;36:1114-5

17 Smith T, Sime P. A survey of clinical academic staffing levels in UK medical and dental Schools: a report to the Council for Heads of Medical Schools. London: Council for Heads of Medical Schools, 2001.

(Accepted 17 February 2004)

\title{
Commentary: Promises and delivery-a research imperative for new approaches to medical education
}

David Prideaux

Howe et al describe the approaches to medical education in the four new medical schools in the United Kingdom. ${ }^{1}$ The new programmes embrace wider selection procedures, spiral curriculums, fitness to practise, integrated clinical experiences, and comprehensive assessment processes. The reforms are part of wider changes throughout British medical education, and Britain is not alone in this endeavour. In Australia there have been similar changes in existing and new medical schools. ${ }^{2}$ Indeed, the past 20 years have seen worldwide reforms if measures such as adopting problem based learning and creating medical education units are to be taken as key indicators.

Several external factors have been driving the reforms, and their importance was apparent in my study of four international medical schools that were changing their education programmes or creating new ones (unpublished data). In both Britain and Australia the external forces have come through funding from governments with clear agendas to change both the quality and quantity of future entrants to the medical workforce.
External support does not come without obligations. External sponsors want to know if the programmes they support have the desired impacts on the healthcare system. Providing the answer to this type of question is not easy, as some writers on medical education reforms in North America have shown. ${ }^{3}$ Determining which attributes of graduates from innovative medical schools are important and how long they are retained as careers progress are complex problems. But therein lies an opportunity for staff in the new or changed medical schools.

Funding for workforce reforms frequently targets teaching initiatives without investing in research. Howe et al outline some of the difficulties of conducting medical education research at the same time as establishing new education programmes and the implications of this for the scholarship of medical education where programmes are located in otherwise researchrich environments.

There is at least one profitable direction for research in new or changed medical schools. Impact or outcome research may provide external sponsors with
Department of Medical Education Flinders University, GPO Box 2100, Adelaide, South Australia 5001 David Prideaux head

david.prideaux@ flinders.edu.au 
the information they need, but, if rigorously conducted, it will also provide generalisable findings for the wider medical education community. It will require the construction of tracking databases and associated research designs. Such work is not necessarily new and has been successfully applied at single institutions. ${ }^{4}$ However, it has the potential to provide more powerful findings if conducted collaboratively, with medical schools combining data on different approaches and their outcomes. The Australian medical schools have laid the foundations for such an approach though the Committee of Deans Medical School Outcomes Database Project. It remains to be seen whether it and future projects involving other innovative schools can provide the research evidence that Murray, for example, suggests can be generated in this time of change in medical education. ${ }^{5}$

Competing interests: None declared.

1 Howe A, Campion P, Searle J, Smith H. New perspectives-approaches to medical education at four new UK medical schools. BMJ 2004;329:327 31

2 Prideaux D, Saunders N, Schofield K, Wing L, Gordon J, Hays R, et al. Prideaux D, Saunders N, Schofield K, Wing L, Gordo
Country report. Australia. Med Educ 2001;35:495-504.

3 Friedman CP, de Bliek R, Greer DS, Mennin SP, Norman GR, Sheps CG, et al. Charting the winds of change: evaluating innovative medical curricula. Acad Med 1990;65:8-14.

4 Hojat M, Gonnella JS, Veloski JJ, Erdmann J. Jefferson Medical College longitudinal study: a prototype for evaluation of changes. Educ Health 1996;9:99-113.

5 Murray E. Challenges in educational research. Med Educ 2002;36:110-1.

\title{
The ethics of medical education
}

\author{
Reshma Jagsi, Lisa Soleymani Lehmann
}

Medical students and doctors in training need to hone their clinical skills on patients to make themselves better doctors, but patients may not benefit directly from such attention. Jagsi and Lehmann consider this ethical dilemma and suggest ways to minimise the potential harm to patients

Department of Radiation Oncology, Massachusetts General Hospital, Harvard Medical School, Boston, MA USA

USA
Reshma Jagsi resident in radiation oncology

Division of General Medicine and Primary Care, Brigham and Women's Hospital, Harvard Medical School, 1620 Tremont Street, Boston, MA 02120-1613, USA Lisa Soleymani Lehmann instructor in medicine and medical ethics

Correspondence to: L S Lehmann llehmann1@ partners.org

BMJ 2004;329:332-4 also balance the good to society and potential benefit to individual participants against potential harm to those participants, avoid the unfair distribution of risks and benefits, and maintain respect for patient autonomy. Although education and research have different goals, their similarities are sufficient to allow for fruitful discussion based on this analogy.

In this article we apply three principles of research ethics - respect for individuals, beneficence, and distributive justice-to medical education in order to review current practice and guide further research and policy.

\section{Respect for individuals}

Western philosophers have long argued that human beings have an inherent personal dignity that merits respect for its own sake. To use people only as a means to an end-as is the case when patients are the objects of medical education or research without meaningful consent-violates that fundamental principle.

Evidence suggests that the current practice of medical education does not always accord adequate respect to patients. In one US survey, only $38 \%$ of responding teaching hospitals claimed that they informed patients that students would be involved in their care. ${ }^{11}$ Other studies show that students and their supervisors sometimes misrepresent or inadequately explain students' status. ${ }^{12}$ Moreover, student conscientiousness about disclosing their status seems to decay over the course of training. ${ }^{13}$ Patient surveys confirm that they receive inadequate information about trainees' roles. ${ }^{14}$

Procedures to ensure meaningful consent from patients to participation in medical education are therefore necessary. Patients must be fully informed of the training status and experience of all staff caring for them and must comprehend the risks, benefits, and alternatives. The proximity of consent to individual procedures is crucial, and a "blanket" consent at admission is insufficient. 